\title{
Profile of invasive group A and group B Streptococcal infections in patients hospitalised at the University Hospital for Infectious Diseases "Dr. Fran Mihaljević" during the period from 2011 to 2018
} \author{
od 2011. do 2018. godine \\ Lana Šepec Rožmarić' , Suzana Bukovski2,3,4 \\ ${ }^{1}$ Department of Public Health Koprivnica County, Croatia \\ 2 University Hospital for Infectious Diseases „Dr. Fran Mihaljević”, Zagreb, Croatia \\ ${ }^{3}$ Catholic University of Croatia, Zagreb, Croatia \\ ${ }^{4}$ Faculty of Dental Medicine and Health Osijek, Josip Juraj Strossmayer University of Osijek, Croatia
}

Profil invazivnih infekcija izazvanih invazivnim sojevima streptokoka grupe A i B kod bolesnika hospitaliziranih u Klinici za infektivne bolesti „Dr. Fran Mihaljević" u razdoblju

Keywords:

beta-hemolytic streptococci

invasive infection

blood culture

intensive care unit

Ključne riječi:

beta hemolitički streptokok

invazivna infekcija

hemokultura

jedinica za intenzivno liječenje

Primljeno: 15-02-2020

Received: 15-02-2020

Prihvaćeno: $17-03-2020$

Accepted: 17-03-2020

$\square$ Correspondence:

Lana Šepec Rožmarić, MD

Department of Clinical Microbiology, Department of Public

Health Koprivnica County, Tomislava dr. Bardeka 10/10,

48000 Koprivnica, Croatia

e-mail: lanasepecrozmaric@gmail.com

\begin{abstract}
Aim: Beta-haemolytic streptococci (BHS) rarely cause invasive disease (ID). Usually the most common cause of ID is group B BHS (BHS-B). However, in our recent routine work higher number of group A BHS (BHS-A) isolates from blood was noted. The aim of this study was to report trends and findings by group BHS-A and BHS-B causing laboratory confirmed disease from 2011 to 2018 at the University Hospital for Infectious Diseases „Dr. Fran Mihaljević".

Methods: Data on patients from the electronic database of microbiological laboratory at UHID for the period 20112018 was collected and analysed.

Results: During the period 2011-2018, 151 BHS A and B were identified from normally sterile body sites. Most isolates were from blood cultures (96.7\%). BHS-A and BHS-B were isolated almost equally. The highest number of isolates was recorded in 2012 and 2017. The number of BHS A isolates peaked in 2012,54\% more than BHS-B, and 50\% more in 2016. Children presented 19.9\% of patients, and were mostly isolated with BHS-A. 80.1\% patients were adults. Adults predominated in the age group $>65$ years. 12 children and 18 adults were hospitalised in intensive care unit. Conclusion: Invasive group A and group B streptococcal infections predominantly affect most vulnerable age groups, children and elderly. In this study invasive BHS disease is most common among adults above 65 years of age. BHS-A was most common cause of invasive disease among paediatric patients as well as in the age group above 65 years. Typing and characterization of BHS-A isolates due to its characteristics should be foreseen as important diagnostic tool, especially to monitor changes in virulence and to prevent potential outbreaks.
\end{abstract}

Sažetak

Cilj: Beta hemolitički streptokoki (BHS) su rjeđe uzročnici invazivne bolesti (IB). Očekivano je BHS grupe B češći izolat kod bolesnika s IB. Međutim, u rutinskom radu u posljednje je vrijeme uočeno sve više izolata BHS grupe A iz krvi. Stoga je cilj bio analizirati pojavnost i učestalost IB uzrokovane BHS grupe A i B kod bolesnika liječenih u Klinici za infektivne bolesti (KIB) u dužem periodu.

Metode: Podatci o bolesnicima i BHS za razdoblje 2011.- 2018. godine prikupljeni su iz elektronske baze podataka Centralnog dijagnostičkog laboratorija KIB te je učinjena podatkovna analiza.

Rezultati: Tijekom razdoblja od 2011. do 2018. god. iz primarno sterilnih uzoraka identificirano je 151 BHS A i B. Većina izolata bila je iz krvi - 96,7\%. Podjednako je bilo izolata BHS A i BHS B. Najviše izolata zabilježeno je 2012. i 2017. godine. BHS A izolata bilo je najviše u 2012. godini, 54\% više od BHS B, a u 2016.g. 50 \% više od broja BHS B izolata. U skupini djece koja je činila 19,9\% bolesnika, najčešći je izolat bio BHS A. Odrasli su činili $80,1 \%$ bolesnika. Većina oboljelih bili su stariji od 65 godina. Na odjelima za intenzivno liječenje hospitalizirano je 12 djece i 18 odraslih.

Zaključak: Invazivne infekcije BHS A i B utječu na najranjivije dobne skupine, djecu i starije. U našoj studiji oboljeli su najčešće bili bolesnici stariji od 65 godina. BHS-A bio je češće uzrok IB u dječjoj skupini. Zbog karakteristika BHS-A bilo bi dobro imati mogućnost upotpuniti dijagnostiku karakterizacijom BHS-A izolata osobito u nadzoru promjena u virulenciji. To bi također bio doprinos u praćenju i evidenciji potencijalnih epidemija. 


\section{Introduction}

Beta-hemolytic streptococci (BHS) belonging to the Lancefield group A and B cause broad spectrum of infectious diseases in humans, but rarely cause invasive disease. Infectious diseases range from less severe such as sore throat and wound infections to potentially fatal clinical manifestations such as meningitis, sepsis and necrotising fasciitis. Most infections are acquired within the community. ${ }^{[1,2]}$ Usually the most common cause of invasive disease is BHS-B (Streptococcus agalactiae). However, in our recent routine work higher number of BHS-A isolates from blood was noted. The aim of this study was to report trends and findings by group A and group B invasive beta haemolytic streptococci causing laboratory confirmed disease in the period from 2011 to 2018 at the University Hospital for Infectious Diseases (UHID) „Dr. Fran Mihaljevic’”.

\section{Materials and methods}

Data on patients from the electronic database of microbiological laboratory at UHID for the period 2011-2018 was collected and analysed. The isolates are referred with information on the origin of the isolate, including specimen type and date, patient age, sex and hospital ward. A case of invasive BHS-A and BHS-B disease was defined as isolation of BHS-A or BHS-B from a normally sterile body site. A new case was defined as an invasive isolate with a different Lancefield group within 30 days from the first one. Copy isolates were defined as isolates of the same Lancefield group collected from the same patient within a 30 day period and they were excluded from the data.

\section{Results}

Altogether 151 cases were identified by positive cultures from normally sterile body sites, 73 (48.3\%) group A and 78 (51.7\%) group B. Most strains were isolated from blood cultures (146 samples, 96.7\%, 72 of which were BHS-A and 74 were BHS-B) and the rest from cerebrospinal fluid (four samples or $2.6 \%$, all of which were BHS-B, three children and one adult) and pleural fluid (one sample 0.6\%, BHS-A, adult female) (Figure 1.)

Male and female patients were represented almost equally: 69 female (45.7\%) and 82 male (54.3\%). Sex distribution among BHS-A isolates was: 30 female (41.1\%) and 43 male (58.9\%) patients and among BHS-B isolates: 39 female (50\%) and 39 male (50\%) patients. (Figure 2.)

Altogether 30 patients were children (19.9\%): 23 were infected with BHS-A (76.7\%), and 7 with BHS-B (23.3\%). (Figure 3.)

In total, 121 patients were adults (80.1\%): 50 were infected with BHS-A (41,3\%), and 71 with BHS-B (58.7\%).
Figure 1. Distribution OF POSITIVE CULTURES ACCORDING TO THE SOURCE OF THE CULTURE

SLIKA 1. ZASTUPLJENOST POZITIVNIH KULTURA OVISNO O VRSTI UZORKA

Distribution of positive cultures according to the source of the culture

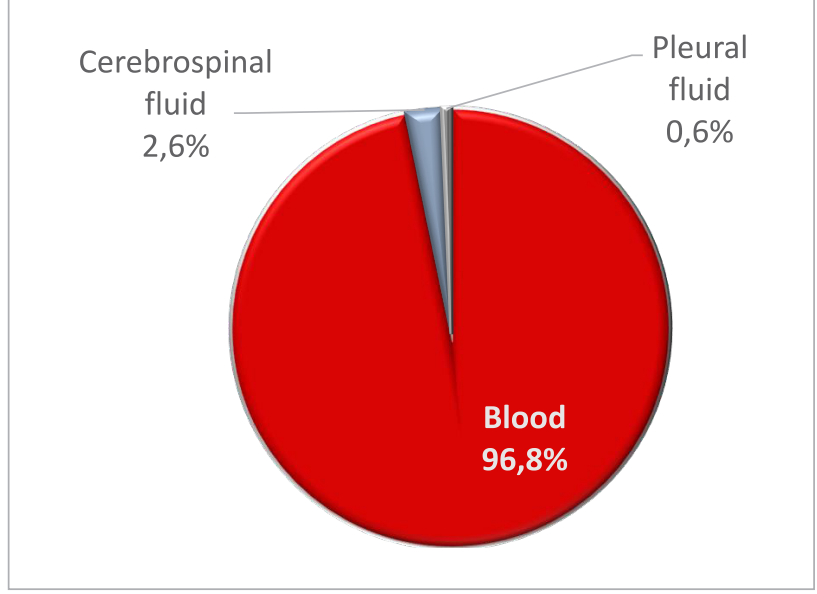

Patients were predominantly adults in past typical retirement age, in the age group $>65$ years old $44.4 \%$ (67 of the total number of patients, 29 of which were BHS-A, $43.3 \%$ and 38 of which were BHS-B, 56.7\%).

Altogether 16 patients (10.6\%) were in the group which includes new-borns, infants and toddlers 0-2 years of age (10 of which were BHS-A, 62.5\% and 6 were BHS-B, 37,5\%), 9 patients (6\%) were pre-schoolers $>2-5$ years old (all of which were BHS-A), four patients $(2,6 \%)$ in the age group $>5-15$ (three were BHS-A, 75\% and one was BHS-B, 25\%), two patients $(1,3 \%)$ in the age group $>15-25$ years (one was BHS-A: 17-year-old female, and one was BHS-B: 23-year-old male), 28 (18,5\%) younger and middle aged working adults: $>25-55$ years old (17 of which was BHS-A, $60,7 \%$ and 11 were BHS-B, 39,3\%), 25 (16,6\%) adults nearing retirement: $>55-65$ years of age (four of which were BHS-A, $16 \%$ and 21 were BHS-B, 84\%). (Figure 4.)

In total, 12 children $(7.9 \%$ of the total number of cases; $40 \%$ of the total number of children) and 18 adults $(11,9 \%$ of the total number of cases; $14,9 \%$ of the total number of adult patients) were hospitalised in intensive care unit (ICU).

The highest number of isolates was recorded in 2012 and 2017. (Figure 5.) The number of BHS-A isolates peaked in 2012, with $54 \%$ more than the number of BHS-B isolates and in $201650 \%$ more BHS-A isolates than BHS-B isolates were recorded.

Seasonal variability was not noted. Average number of patients with invasive BHS-A infection was 9.1 per year and 9.8 with invasive BHS-B infection per year. 
Figure 2. INVASIVE BHS SEROGROUP AND SEX DISTRIBUTION AMONG PATIENTS HOSPITALISED IN UHID IN THE PERIOD 2011 -2018 Slika 2. Spolna Raspodjela bolesnika hospitaliziranih U KIB U RAZDoblju od 2011. Do 2018.g. S ObZirom Na SERogrupu INVAZIVNIH BETA HEMOLITIČIH STREPTOKOKA

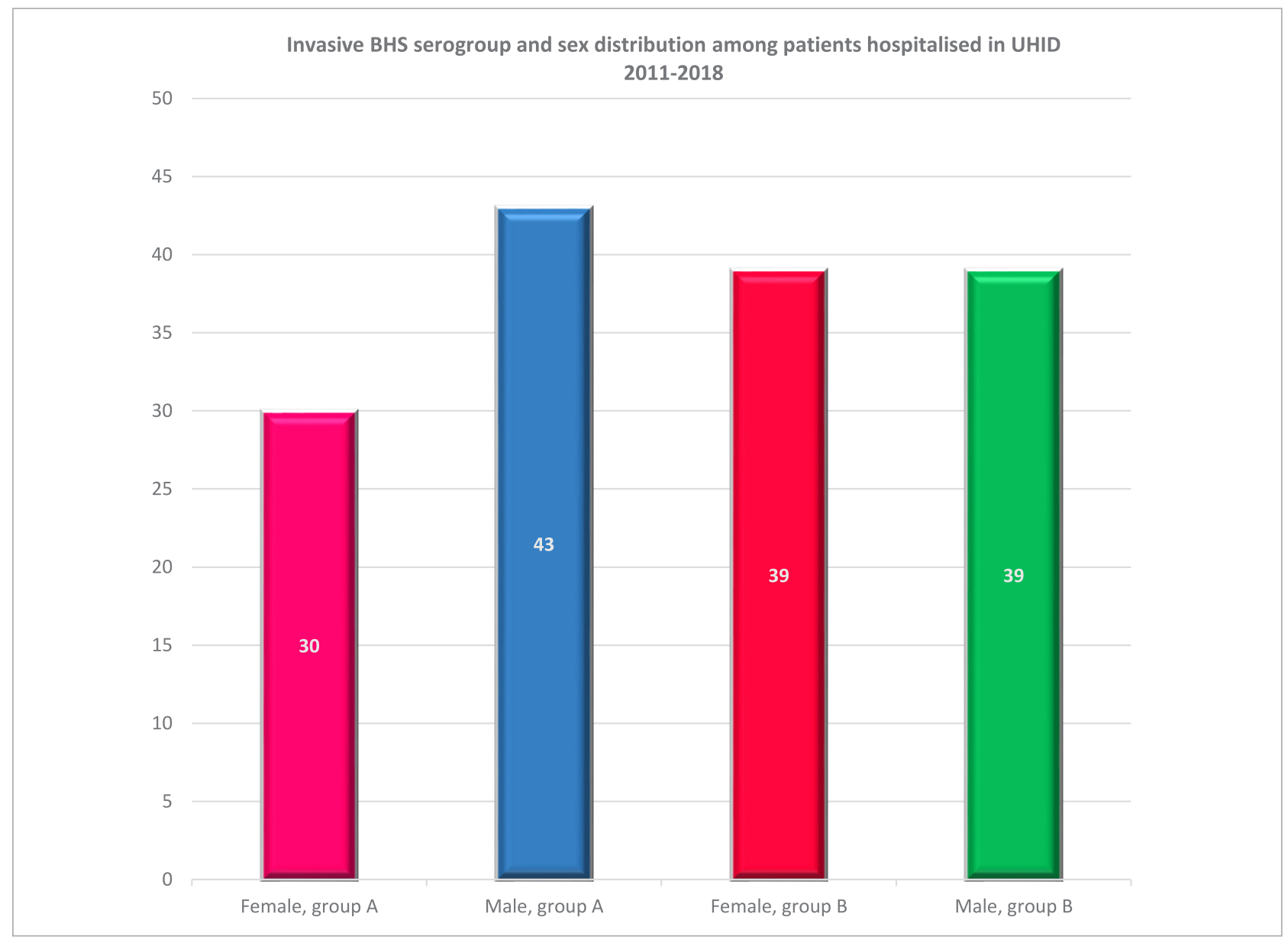

Figure 3. InVASIVE BHS SEROgRoUP DISTRIBUtion AMONG CHILDREN HOSPITALISED IN UHID IN THE PERIOD 2011-2018 Slika 3. Zastupljenost pojedine SERogrupe Beta hemoLITIČKIH STREPTOKOKA KOD DJECE HOSPITALIZIRANE U KIB U RAZDOBLJU OD 2011. DO 2018.G.

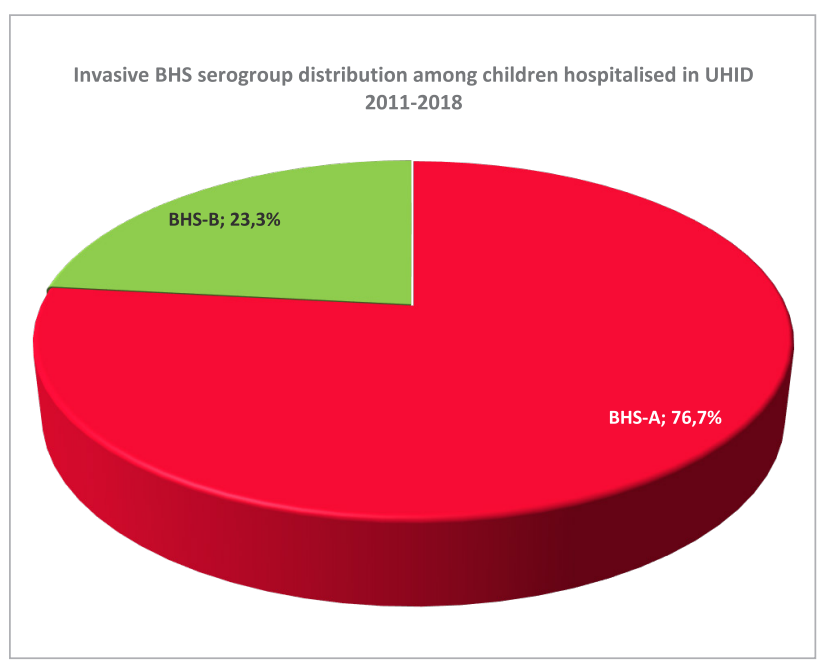

Figure 4. Age Distribution of Patients

SLika 4. Dobna RASPodjela bolesnika

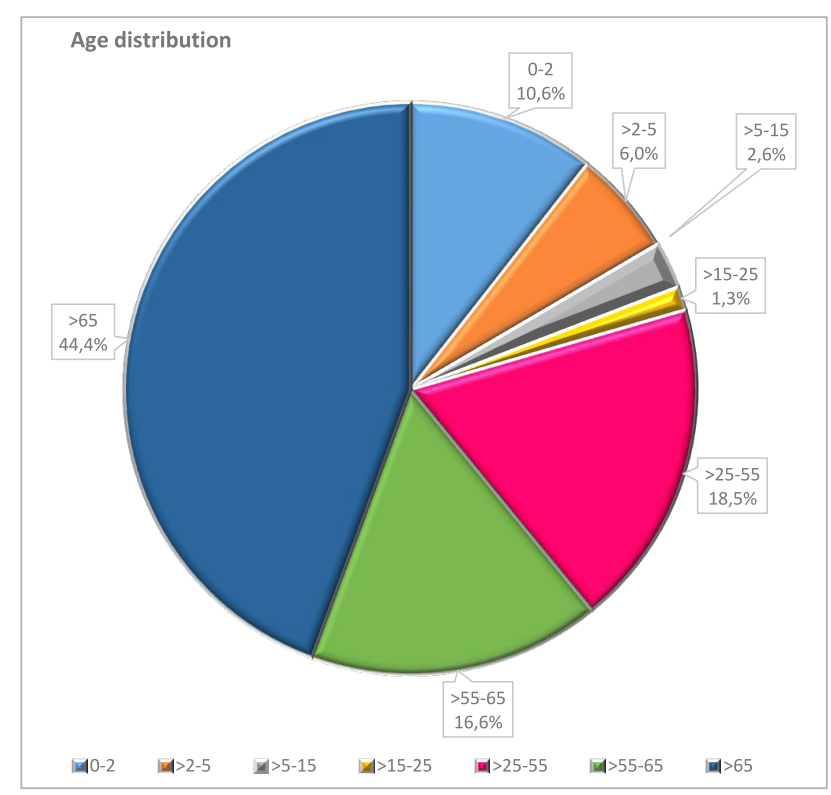


Figure 5. Number of InVASIVE BHS-A AND BHS-B IsOlates PER yeAR

Slika 5. Broj InVAZIVNih BHS-A i BHS-B IZOLATA Po Godini

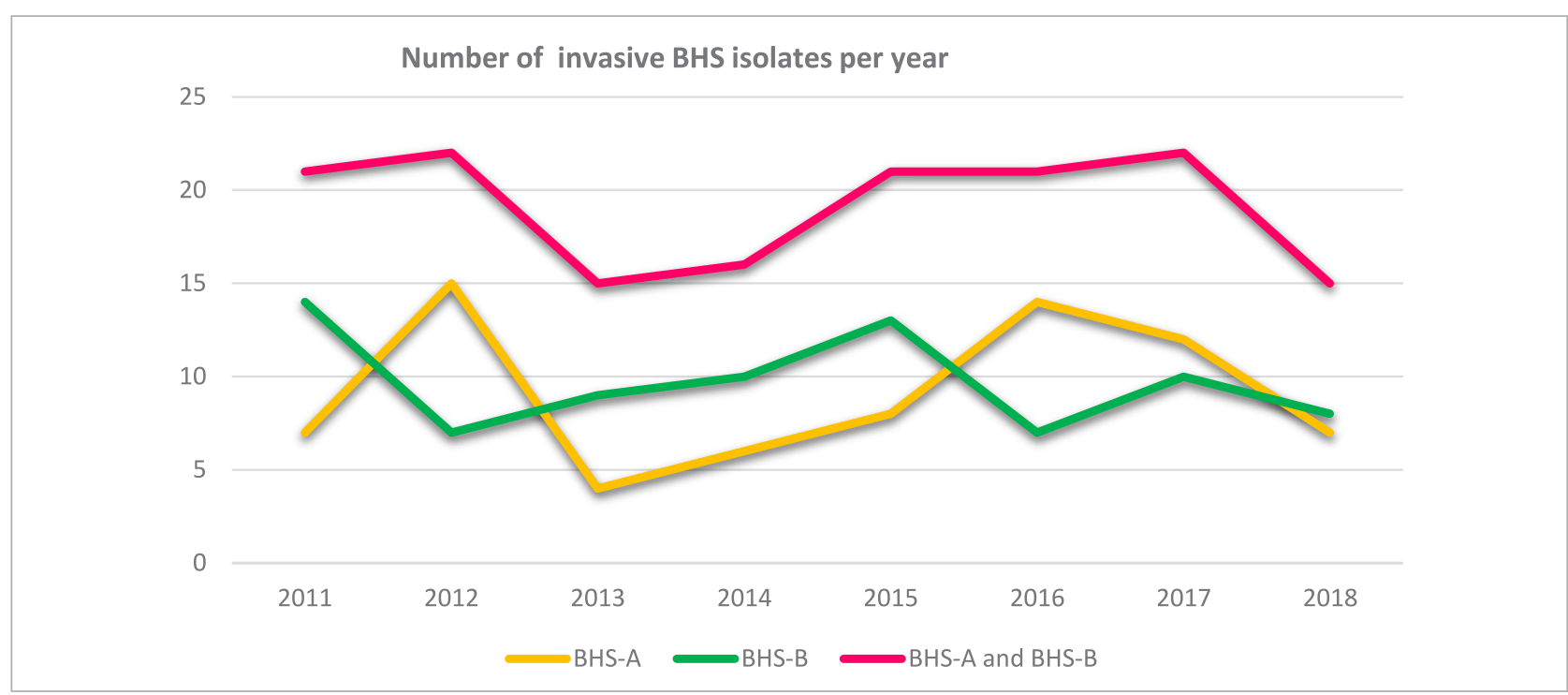

\section{Discussion and conclusion}

Invasive group A and group B Streptococcal infections predominantly affect most vulnerable age groups, children and elderly.

The severity of disease is determined by many BHS-A and BHS-B virulence factors and is clearly host dependent. ${ }^{[1,2,3,4]}$

Streptococcus pyogenes (BHS-A) causes a diverse spectrum of disease. The majority of BHS-A diseases are mild, superficial infections of the throat and skin. Serious consequence of these superficial infections occurs when the infecting strain gains access to deeper tissues, causing invasive infections that include necrotizing fasciitis and Streptococcal toxic shock syndrome (STSS), both of which have high case fatality rates. Another serious consequence of superficial BHS-A infections occurs when an abnormal immune response leads to post-streptococcal sequelae which include Acute Rheumatic Fever (ARF) and Acute Post-Streptococcal Glomerulonephritis, and can result in the long-term morbidities: rheumatic heart disease and chronic kidney disease that account for most of the global disease burden for this pathogen. ${ }^{[4]}$ Beginning in the late 1980s, a marked increase in the number of invasive BHS-A infections was observed in the USA and Europe. Invasive BHS-A disease is constantly present to this date due to genetic changes in circulating BHS-A strains and changes in host susceptibility to infection. ${ }^{[4]}$

Streptococcus agalactiae (BHS-B) is a commensal of the gastrointestinal tract and vagina and has been estimated to colonize the vagina in $10-35 \%$ of pregnant women. BHS-B is a known cause of puerperal sepsis and meningitis, and in recent years, an increasing in- cidence of BHS-B infections among the elderly, mainly bacteraemia and meningitis, has been observed in the industrialized part of the world. ${ }^{[2]}$

In our study invasive BHS disease is most common among adults above 65 years of age. National laboratory- based surveillance studies in Denmark and other Western countries reported similar results. ${ }^{[1]}$

The number of cases with invasive group $A$ and group B streptococcal infections per year for analysed period 2011 to 2018 was constant. To our knowledge this is the first laboratory- based surveillance study on the profile of invasive BHS-A and BHS-B infections in Croatia. Typing and characterization of BHS isolates should be foreseen as important tool to monitor changes in the virulence of Croatian invasive streptococcal isolates and to prevent potential outbreaks.

\section{Conflict of interest statement}

None.

\section{REFERENCES}

${ }^{[1]}$ Lambertsen LM, Ingels H, Schønheyder HC, Hoffmann S. Danish Streptococcal Surveillance Collaboration Group 2011. Nationwide laboratory-based surveillance of invasive beta-haemolytic streptococci in Denmark from 2005 to 2011. Clin Microbiol Infect 2014;20(4):O216-O223.

${ }^{[2]}$ Slotved HC, Hoffmann S. The Epidemiology of Invasive Group B Streptococcus in Denmark From 2005 to 2018. Front Public Health 2020;8:40. Published 2020 Mar 10.

${ }^{[3]}$ Luca-Harari B, Darenberg J, Neal S, et al. Clinical and microbiological characteristics of severe Streptococcus pyogenes disease in Europe. J Clin Microbiol 2009;47(4):1155-1165.

${ }^{[4]}$ Barnett TC, Bowen AC, Carapetis JR. The fall and rise of Group A Streptococcus diseases [published online ahead of print, 2018 Aug 15]. Epidemiol Infect 2018;147:1-6. 